\title{
Belgeo
}

Revue belge de géographie

3 | 2001

Poverty, social exclusion and coping strategies in rural Europe

\section{Coping with declining income opportunities in Norwegian rural households}

\section{Sveinung Eikeland}

\section{(2) OpenEdition}

\section{Journals}

Electronic version

URL: http://journals.openedition.org/belgeo/15108

DOI: $10.4000 /$ belgeo. 15108

ISSN: 2294-9135

Publisher:

National Committee of Geography of Belgium, Société Royale Belge de Géographie

\section{Printed version}

Date of publication: 30 September 2001

Number of pages: $215-230$

ISSN: 1377-2368

\section{Electronic reference}

Sveinung Eikeland, « Coping with declining income opportunities in Norwegian rural households », Belgeo [Online], 3 | 2001, Online since 12 June 2015, connection on 08 May 2019. URL : http:// journals.openedition.org/belgeo/15108; DOI : 10.4000/belgeo.15108

This text was automatically generated on 8 May 2019.

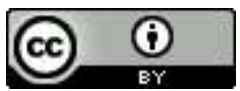

Belgeo est mis à disposition selon les termes de la licence Creative Commons Attribution 4.0 International. 


\title{
Coping with declining income opportunities in Norwegian rural households ${ }^{1}$
}

\author{
Sveinung Eikeland
}

\section{Introduction}

1 In an analysis of the socio-political prerequisites for developing processes in the European periphery 1780-1914 Iván T. Berend and Gyôrgi Rànki (1982, pp.32- 33) emphasise the absence of feudal traditions in Norway, and that historically the country was governed by elected kings who guaranteed all rights, for example to fishing and hunting (Berend \& Ranki, 1982, pp.32-33). When an urban middle class later evolved and developed a monopoly of trade and industry, this was stopped in its tracks in the 1800 s by the rural population. People living along the coast had the rights to fish in inshore waters. Thus anyone with a boat could harvest these resources. In some areas there were rights of commons over forestry as over fishing, but in inland areas most forests were in private hands, that is they were owned by smallholders. The rights of country people to forestry and fishing were established so that they could raise money, for example to put up new farm buildings, to pay taxes and duties and to cover other needs which they could not meet from what they produced on their own holdings.

2 Thus the settlement of rural Norway was distinguished by the fact that in the main people had the right to exploit any natural resources outside the urban areas. It was relatively easy for anyone to get hold of land to grow corn and to raise livestock for meat or for dairying. Even though land was in private ownership, it was only in a few parts of Norway that land was controlled by large landowners and that these prevented other members of the community having access to land of their own. Probably one of the reasons for this was that much land in Norway is so poor in agricultural terms that it doesn't offer the basis for any great economic wealth. Traditional land use in Norway, then as now, consisted mainly in the production of hay for use in dairy farming and 
livestock production. Therefore farm properties in outlying areas of Norway have had little capital value until very recently.

Population e.g. increases meant an enlargement of the already settled areas, and the cultivation of steadily more marginal and remote pieces of land. Until the Second World War remote areas (particularly the Northern parts) were an alternative to the mid-west America: Poor people could find economic benefit based on exploiting nature resources no one owned. Thus the thinly scattered settlement patterns characteristic of Norway gave the property- less classes more options than they had in other parts of Europe. In countries where population was concentrated in relatively large villages, people did not have the right to build a house outside the villages if they wanted to. In these countries, nearly all land was in private hands, whereas in Norway there was plenty of common land available (Brox, 1984, p.21).

4 Therefore it was the household, whose members found it relatively easy to acquire the ownership of resources, which formed the basic economic institution in large parts of rural Norway. The householder was thus able to reject unfavourable working arrangements and uncertain wage labour with private companies, in a way which was not possible for poor people in countries where natural resources were less accessible. However, not everybody managed to exploit the land and coastal resources. Fredrik Barth and others (1966) claimed that a big proportion of rural people without properties had some kinds of physical handicaps. Later on, when most of the land resources were distributed, the inheritance institution became more central.

5 As the householder "balanced his books" with the aid of income from fishing and forestry, his finances were of course vulnerable to price changes in the markets for the various timber and fisheries products. The rural economy was however strengthened by the fact that rural householders had one foot in the market economy and one in rural self-sufficiency. For example, lay-offs in the building trade or in construction would lead not to unemployment (Brox, 1980) as such, but to higher amounts of timber extraction from the forests or to an increased effort in the seasonal fisheries. Explanations of social inequality in rural Norway probably have more to do with differences in the availability of manpower than with the exclusion of some households from land ownership. That is, poor households had less manpower available for harvesting natural resources, and possibly included a number of children or elderly relatives who were unable to generate income for the household. In households where the ablebodied consisted of just the husband and wife, it often took all their efforts to maintain their way of life, and they would slip behind other households where access to greater manpower enabled them to build up enough capital to replace and improve their tools and equipment.

This was however also an economic structure which developed a socio-economic clash of interests. Earnings from fishing were dependent on what local fish merchants were prepared to pay. With the mechanisation of the fishing industry, the fishermen got into debt with the merchants and prices became depressed. However, in the 1930s Norwegian fishermen gained political protection in that the fishermen's national organisations won the right to set prices. Meanwhile, technological developments within the agricultural sector meant that households could produce more than they needed for their own use. Farmers founded farmers' co-operatives which also won political protection in that they were granted trading monopolies on farm produce. Norwegian producers' organisations still have these rights to this day, and their policy has been one of equality of access to the "marketplace" for all farmers, with similar prices guaranteed over the whole country. 
This has contributed to the fact that the rural population is still very evenly spread out, with large distances between farms, as there has been no need to concentrate production close to centres of population or distribution. This article presents an analysis of how modern-day households in outlying regions of Norway manage to make ends meet when the significance both of their access to manpower and of the traditional Norwegian political regime is reduced. My starting point is the earning strategies of the rural household in classical peripheral situations. These are in the Norwegian coastal and inland areas where householders have few alternative sources of income to selfemployment. The article addresses questions such as: how important is land and property ownership as a basis for income generation in peripheral regions of rural Norway today? What opportunities for income generation based on property ownership are available to people in these areas? What factors characterise the relationship of rural households to the market economy? What marginalisation processes are obvious? The article focuses, then, on the response of outlying households in rural Norway to a scarcity of opportunities for earning money in a modern society.

\section{How incomes are made up in outlying areas of Norway}

\section{"Scarcity and shortage"}

7 My principal starting point is the person in the classical outlying area situation for whom there is no locally available alternative use of his labour than to work in his own enterprise. It was the pioneering Norwegian rural sociologist Ottar Brox who in his analysis of the rural household in the 1960s first looked at how such households adapted to the limitations of peripheral societies. Above all he demonstrated the rationality of the householders' strategies in relation to the market economy and its modernisation. Compared with other rural sociological research of that time, Brox "gave the people of the peripheral areas their rationality back" (Hersoug, Holm and Maurstad, 1993, p.104). For example, Ottar Brox and Ståle Seierstad (1966, pp.59- 65) showed that in most cases it paid better for the rural householder of the 1960s to take work outside the primary sector rather than to produce food for sale. Primary production at that time depended on inefficient machinery and equipment, that is to say it took a great increase in labour input to increase production. Thus the household's surplus labour force had greater economic value in other sectors than on the home farm. This created a pattern of adaptation based either on selfsufficiency, producing a variety of goods, or on the introduction of cash inputs through working outside the primary sector. Such income was generated mainly by the men of the household working away from home for a large part of the year.

8 In the light of this academic starting point, Norwegian research on income generation in the peripheral areas has been marked by analyses of adaptations to situations characterised by "scarcity", "shortage" and "the development of alternatives to onerous commuting and dislocation" (Brox and Seierstad, 1966; Brox, 1984; Seierstad, 1991, Nilsen, 1991; Nilsen, 1998). Even though the surplus labour force within the household had a higher economic value in other sectors, the lack of opportunities to bring in a cash income locally meant that the households in the peripheral areas produced as many as possible of the goods they needed to maintain a culturally acceptable living standard themselves (Brox and Seierstad, 1966; Brox ,1984, p.143). But long distances to produce 
markets, uncertain sales prospects, lack of capital and lack of availability of goods and services meant that combinations of activities were crucial for the maintenance of household incomes in peripheral areas (Brox, 1984, pp.143-144).

Economic adaptations based on self-employment took place in periods when people could only get a "normal" job by moving away. These types of adaptations were "involuntary" for many, as there were few vacancies in the specialised jobs markets of the rural areas in the 1960s (Seierstad, 1991). Thus when the state welfare sector was built up in rural Norway in the 1970s, this represented a new demand for labour which for many people ousted the alternative combinations of ways of earning a living. However, these new jobs were still mainly located in district and regional centres. For those who didn't want to commute on a weekly basis, because of the phase of life which they found themselves in, the combination approach was still an attractive option (Nilsen, 1991, 1998). Thus many of the new jobs were applied for by people who had not yet established their own households. In this "free" phase of life, many younger men and women started their working careers outside their home areas. They stayed in bedsits but came home on their days off and holidays. However, many of these commuters moved home when they established their own households because the commuting was too much of a strain on the household. Moving home often turned out to involve a transition from participation in a specialised professional working life in the urban centres, for example working in a shop or factory, to an adaptation based on income from several sources. Thus earning strategies in peripheral regions were strongly influenced by household phases. These can be divided into three. The first phase is the household's growth phase. This starts after the household is established and lasts right up till when the children grow up and leave home. The phase in which the household traditionally has the power to change its position has been linked to the earning opportunities available when the children are grown up and able for work, but have not yet moved out. The second phase starts when the first grown up child establishes his or her own household and thus leaves their native household. This is the start of the dispersal phase. The third phase is the dissolution of the household, which ends with the death of the last of the original members of the household.

\section{Combining income sources as a rural way of life}

10 Whereas Norwegian analyses in the "Brox tradition" have mainly emphasised the combination of income sources as a rational economic adaptation to the material and structural conditions and possibilities within a household-based economy, the Danish researcher Thomas Höjup also placed weight on the ideological aspects of such economic adaptations (Höjrup, 1983). He shows that even where the material processes of change should point towards job specialisation, combination work may still be maintained, because people are socialised into economic adaptations based on combining diverse activities. Combinations are a rural way of life. Ways of life consist both of structures and ideologies (Höjrup, 1983, p.20), and ways of life mean that combining incomes from different sources survives as an economic pattern even where we would not expect it to. The reason is that the ideological basis for combining income sources is "rooted in inherited patterns and in relationships between producers, which in the widest possible compass safeguard the individual households within the local community against crises in the market for their products and in the abundance of natural resources" (Höjrup, 1983, p.263). The particular structures of the rural economy oriented around the 
exploitation of natural resources based on individually owned homesteads have thus produced a culture which has survived despite the changes in the employment market. The key to the development of this culture lies largely in systems of rural socialisation from the period before the establishment of the household. During this period, young country people learn to acquire both the knowledge and the attitudes which will affect the organisation of their working lives in the rural situation, even though the structural frameworks have changed.

\section{Restructuring of peripheral rural areas in Norway}

11 Both rural areas themselves and the concept of rurality have been going through changes in the last few decades. Processes of change are portrayed in many ways but can probably be divided into two types (Marsden, Lowe \& Whatmore, 1990). Firstly there is a vertical integration process of the home-based production of foodstuffs, in that economic yields are largely determined by external markets such as for example large groceries chains, rather than by prices laid down in national negotiations between the state and the producers. This has involved both greater control of production by the market and less state support for food production. Meanwhile, farms have gained new value as holiday bases, as homes or second homes and as the basis of initiatives to protect the cultural landscape. Rurality is therefore still tied to land and farm ownership and to the role this plays in the rural economy. As I said in my introduction, the Norwegian countryside is characterised by the small size of individual holdings. Moreover, there have been strict political restrictions on the disposal and usage of such holdings. This has resulted in farmsteads not being used much for holidaying or recreation but for farm-based business enterprises. Another aspect of vertical integration is the introduction of national regulation of the fishing industry. Around 1980, significant sections of the sea-fishery and coastal cod fishery were controlled, so that only those members of the coastal population who were considered professional fishermen at that time were permitted to continue to earn money from fishing. By imposing quotas on these fishermen, the state largely determined earnings from fishing.

Secondly, many rural communities have also undergone a horizontal disintegration process linked to the growth of industrial production. This is characterised by a weakening of the previously strong connections between the local resource base, the local markets, the ownership of the factories and industrial production. The industrial sector is now controlled to a greater extent than previously by the global finance market and by where multinational companies decide to localise their operations. This has brought with it changes in the patterns of business relationships and has probably made many activities more vulnerable. Another aspect of the market developments is the demographic decline in outlying areas of Norway, in that it is now harder than before to sell to local outlets. Households which are developing new products and services aimed at external market segments are thus in the process of creating new types of market integration, with the inevitable challenges involved with large geographical distances to markets. 


\section{Rural households close to and remote from urban areas}

Regional restructuring processes have brought rural households different possibilities of making a living depending on whether they are close to or far from centres of population. The different positions they find themselves in can be illustrated as in table1 below by four ideal types of households.

Categories (III) and (IV) were analysed by the author (Eikeland, 1999), who showed that households of type (III) often choose to exploit their landholdings to earn a living in a new way rather than to seek fulltime work elsewhere. These new business activities are based on the recreational or free-time markets. Type (IV) households on the other hand probably took work in the urban jobs market largely because they lacked resources in the form of landholdings which could be used as a basis for rejecting wage labour. This article attempts to put some flesh on the bones of household types (I) and (II).

Table 1. Strategic positions of rural households with and without landholdings, close to and remote from urban areas.

\begin{tabular}{|l|c|c|}
\hline & Remote household & $\begin{array}{c}\text { Household } \\
\text { near to a town }\end{array}$ \\
\hline $\begin{array}{l}\text { Household } \\
\text { with landholding }\end{array}$ & (I) & (III) \\
\hline $\begin{array}{l}\text { Household } \\
\text { without landholding }\end{array}$ & (II) & (IV) \\
\hline
\end{tabular}

\section{Methodology and data selection}

\section{Geographical range}

15 We have defined 328 (out of 435) Norwegian kommunar ${ }^{2}$ as rural communes. These are defined as having no town or urban area with a population of more than 5,000 inhabitants, and the proportion of those in employment who are working in primary industries should be at least twothirds of the national average. These outlying communes make up $82 \%$ of the geographical area of Norway but have only $29 \%$ of the labour force (Eikeland and Lie, 1999). In the project "Pluriactivity in Rural Norway" data were collected in 10 of the 328 rural municipalities, 5 of them localised close to towns and 5 in remote areas. Most of the analyses in the article is based on data from the 5 most outlying communes. These communes are parts of small employment market regions, i.e. regions with less than 10,000 employees ${ }^{3}$.

\section{Extent of household adaptations}

The extent to which households derive income from combinations of business activities was analysed with the help of the National register of companies. This was supplemented with the fishermen's register and the list of farmers in receipt of subsidies. The 
companies register includes all registered businesses with their key personnel. People combining different sources or earnings were selected partly on the basis of their appearing twice or more in these lists, partly by going through the lists with local informants. These were mostly business leaders or other people with good knowledge of local business life. People bringing in earnings both from wage labour and from their own business activities were identified by correlating the supplemented companies register with the central employment register.

In the 5 communes we have classified as outlying communes, $23 \%$ of people active in business are also registered as in receipt of wages elsewhere. Our analysis is based on responses from $72 \%$ of these, so we lack information from $28 \%$. Moreover there is a bias in that $85 \%$ of those registered are men. This points to a significant underreporting of female participation in business activities, since joint enterprises engaged in by married couples are mainly registered in the man's name.

\section{Earning strategies}

Household earning strategies in pluriactive households were analysed by means of longer interviews with people who did not see wage labour as an alternative to their own combinations of business activities. Interviews took between 25 minutes and 2 hours and interviewees were selected at random from the list of households combining incomes sources which the statistical analysis was based. There were 29 households on the list (22 farming households and 7 others), in different phases of development.

\section{Income generation based on access to land ownership and natural resources}

\section{Land ownership is important for income generation}

$53 \%$ of people carrying out a business and $12 \%$ of the total workforce in the 10 Norwegian rural communities selected for the analysis earn income from more than one business or have income from wage labour in addition to their business income (Eikeland and Lie, 1999). $73 \%$ of those carrying on a business do so with a basis in farming. This means that even today the ownership of farmsteads is a very important basis for income generation in rural households which are unable to secure sufficient income from a single business activity. $37 \%$ of all rural householders who are self-employed or running their own businesses do so by deriving incomes from several different ways of using their landholdings.

\section{New frameworks for rural ways of life}

Pluriactive householders with land living in the 5 remote communes describe themselves as farmers. They need additional incomes and they judge the opportunities for normal wage labour without commuting or moving away to be small. They do not necessarily all consider that moving would be onerous; the most important barriers against moving are rather a feeling of social duty that they should continue to live on and work the farm as their family did before them. This is linked to a system of land tenure which depends on rights derived from continuous occupancy or usage. This is underlined by Thomas 
Höjrup's emphasis (op.cit.) on the way rural systems of socialisation create attitudes and cultures which are central to rural ways of life. Such attitudes linked to the value of looking after one's property are not necessarily those which best promote an economic surplus; in many cases, earnings from farming are not the most important for the household. When in the 1980s and 1990s the authorities reduced state support for traditional farming, householders began to feel that they had to develop new earning strategies in order to maintain their ways of life. The actual starting point was new developments in sheep farming, as well as in small-scale dairy farming. The situation was different for each of these types of farming. With sheep farming, changes in agricultural policy in the 1990s necessitated a sharp increase in the numbers of sheep to be fed and housed over winter in order to be able to stay in business. Households needing additional income have either invested in bigger farm buildings in order to be able to increase stocking levels - or the lack of available extra acreage has made it impossible to increase flock sizes. In the first case, the households needed new incomes to justify their investments; in the second they needed them to compensate for being unable to increase their flock sizes. In dairy farming, state policy limits the expansion of production. Farmers have large farm buildings and enough rough grazing, but the milk quota system makes it imprudent to increase production. Therefore the householders needed new sources of income to maintain or increase their total earnings.

Therefore, our starting point is a situation of stagnation or declining incomes from the specialised meat and milk production which had been developed under the aegis of the Norwegian policies of the 1960s and 1970s for promoting farming in outlying areas. At the same time we have a situation where households are socialised into rural ways of life. However there are no possibilities for compensating for declining incomes by increasing production, despite easy access to capital. Effective capital outlay is particularly relevant to milk production, which is already characterised by over-investment. The problem with sheep-farming is that the most important conditions for increasing production involve making significant new investments at a time when the profitability of the business is low.

\section{Earning strategies}

In the 5 most remote municipalities I have data from 283 pluriactive farming households which between them carry out 844 income-generating activities. $69 \%$ of these activities are based in property ownership or rights to the use of common resources. They include forestry, fishing, catering, B\&B accommodation and letting of holiday houses. This illustrates the central place which property ownership and rights of access to resources occupy in the earning strategies of the Norwegian rural household. My data also clarifies the interplay between traditional land use and the new activities. Some households expand on traditional farming practices, the most important examples being going into pig farming and potato production. These products supplement the sheep and dairying business, and are sold through the existing producers' organisations. Others have started so-called para-agricultural activities (Fuller, 1990, p.367), which involve the direct retail sale of home-grown produce. Such adaptations are however problematic in outlying areas as the distances to markets are large. It has also been apparent that while farmers relatively close to towns have succeeded in developing such strategies (Eikeland, 1999), those in outlying areas have been stuck with the trading system developed by the 
farmers' co-operatives in the 1930s, so have remained vulnerable to changes in central agricultural policy and unable to exploit new markets. In our sample it is nevertheless the case that organically grown strawberries, flowers and vegetables can be sold in this way. In most cases however, additional earnings have come from activities which do not traditionally come under farming, but which exploit the fact that the households own property or have rights to the use of natural resources: the letting of holiday homes and cabins to tourists and for public use, the letting of shooting and fishing rights, the extraction, processing and sale of sand, gravel, minerals, moss ${ }^{4}$ and timber.

The high incidence of such adaptations confirms that income generation in rural parts of Norway with decreasing income opportunities is strongly linked to such opportunities, but also that this is how rural people have addressed the problem of declining incomes from traditional forms of production. A central feature of this system is that householders become qualified to exploit such additional earnings possibilities in the period before they take over responsibility for the farm, and preferably also before they establish their own household. This period, as mentioned above, is characterised by people working over a wider geographical area and also in a more specialised form of employment than when they are starting families (Nilsen, 1991, 1998). In this way, farmers' sons develop competence in the use of machinery, in building work and in forestry. This is a special feature of rural socialisation today, and is linked to the acquisition of informal qualifications in the form of skills in the repair and maintenance of agricultural equipment as well in the utilisation of the moorlands and uplands (Höjrup, 1983, p.28, pp.66-69). It is with this knowledge and skills base that many take over the farm property, some willingly and some unwillingly, but all with feelings of obligation. These accumulated qualifications thus become a condition for being able to develop both the farm itself and a complete earnings mix.

This "qualification process" also affects how work is distributed between the sexes in the farming household. Generally speaking it looks as if household members who are employed off the farm don't look after the animals. Since not much wage labour is available, it is above all the gender-based distribution of work in supplementary activities which determines the division of labour on the farm. Forestry and contract work are examples of such activities, and on farms where the men are working in these occupations it is the women who look after the sheep. On the other hand there are more opportunities for women to get jobs in the public services, for example as home helps, cleaners and postwomen. In these cases it is the men who look after the animals. It is also the women who tend to look after the administration of holiday cabins and the running of cafés. These tasks would seem to be based at home, so that they can be combined with responsibility for livestock. However, in one case, running a café involved working away from the farmstead, and in that case it was the man who looked after the sheep. Thus there is a pattern in this, although we don't know whether it is the men's or the women's activities which are prioritised in the choice between off-farm activities.

Table 2 shows the extent of activities I have discussed above. Forestry is still the most important, but other occupations are also of significance.

The increased vertical integration of food production and the falling incomes this results in for farmers in outlying regions is therefore handled by exploiting the opportunities for bringing in money from property ownership and common resources. Thus the farmers develop alternatives to fodder production, but earnings from the traditional activity of forestry are still much more important than new sources of income. Fishing is a more 
common way of making some extra money than is catering or providing accommodation, even though the regulation of the fishing industry over the last few decades has militated against such adaptations. Probably the reason for this pattern is that forestry and fisheries resources are relatively easily accessible in comparison with the leisure market.

\section{Earning strategies in households' expansion phase}

A characteristic of the households in danger of being marginalised is that it looks like they are in the early stages of their development. Many of them have recently taken over the property, they have young children, and as one generation gives way to the next, new ways of making a living from the farm holding are introduced. The linkage to this phase of household development distinguishes the development of these particular earning strategies from other types of strategies, for example those of households of type (II) and III). Probably the reason for this is linked to the new economic demands facing the young household, in combination with the way of life they have grown up with which inclines them to develop those strategies based on farm ownership.

Table 2. The extent of income sources in outlying pluriactive Norwegian farm households. Forestry is set at $100(\mathrm{~N}=136)$.

\begin{tabular}{|l|c|c|}
\hline Activity & Index & $\begin{array}{c}\text { Number of } \\
\text { household members } \\
\text { carrying out the activity }\end{array}$ \\
\hline Forestry & 100 & 136 \\
Letting of property & 37 & 50 \\
Fishing and fish farming & 31 & 42 \\
$\begin{array}{l}\text { Processing of game and fish, } \\
\text { extraction of minerals, craft work } \\
\text { and other home-made produce }\end{array}$ & 27 & 37 \\
Accommodation and catering & 18 & 25 \\
\hline
\end{tabular}

\section{Market-based earning strategies}

\section{New processes}

I stated in my introduction that processes of disintegration between rural households and markets were linked to two conditions. The first is the local market situation and its depression due to demographic decline. This means that some enterprises can't find a big enough customer base to support a full-time operation. The most important case is that of the small family grocery shops; these have suffered from the reduced customer base and their owners are now dependent on permanent economic support from other members of the household earning money elsewhere. Secondly, households which run businesses aimed at non-local markets must integrate their businesses into new markets, since for example the new service based enterprises are based on different market relationships from those which were relevant for the traditional production of goods. Examples of new markets are the tourist market and the market for special services, perhaps with a local flavour, such as the restoration of houses and cabins, or 
woodcarving. The customers in these markets are either visitors to the area, or they are from outside the area and wish to purchase products or services from the specific region in question. We see several cases where such an enterprise can be built up into a full-time business, but because new market relationships have to be built up, that won't be the case from the start. A case in point is the production of souvenirs in conjunction with a private museum in somebody's house. For many years this enterprise was supported by income earned by other members of the household, but after the product was incorporated into the tourist market (when tour buses began to feature the museum on their itineraries), it provided full-time work for two and seasonal work for ten people.

Meanwhile the market for grocery shops, which are the first option for households which do not own farms to earn some extra income, is small and getting smaller. Grocery retailing is thus the most important way in which pluriactive householders in outlying areas of Norway derive income from local markets. I collected an example of a complex way of handling these markets from one household which did not derive any income from the shop, but which just took out groceries, in order to reduce their income from other sources than fishing, so as to be able to continue fishing. This was also an adaptation to the introduction by the new fisheries administration of restrictions on the amount of earnings which fishermen could derive from other sources than fishing. In this way the family was able to continue fishing throughout the 1990s, and earnings from inshore fishing enabled the man and his wife to keep the shop going. For the two or three months the man was fishing, the wife would look after the shop. This case is also interesting from the point of view of the conservation of fish stocks. For example, in the 1990s the fisherman didn't take the whole of his quota because his household didn't need the income, and because the fishing would then have taken up too much of the year. This would have affected not only the shop, but also the wife's new venture into tourism and museum facilities. The amount of fish taken was thus determined more by the other household activities than by the availability of fish stocks.

Thus the household's strategies were largely focused on handling the downturn in local markets, a problem linked to the fact that the local fishery had been integrated into the new central administration regime and to the need to build up new market relationships and earning opportunities. My analysis also shows that earnings from other sources are used to support the establishment or running of businesses while the householders are getting their product established in external markets, which takes time. Often one partner will use his or her income to subsidise the household while the other is getting the business going. Particularly important is the development of tourism products. This can be a long process even in popular tourist areas. 
Table 3. Extent of activities in households deriving income from a variety of sources and which do not own farms in the 5 most remote communes. The commonest activity (retailing) has an extent equal to $100(\mathrm{~N}=70)$.

\begin{tabular}{|l|c|c|}
\hline Activity & Index & $\begin{array}{c}\text { Number of } \\
\text { household members } \\
\text { engaged in the activity }\end{array}$ \\
\hline Grocery retailing & 100 & 70 \\
Miscellaneous production* & 61 & 43 \\
B\&B and catering & 58 & 40 \\
Building and construction work & 55 & 39 \\
Transport & 50 & 35 \\
Miscellaneous services** & 47 & 33 \\
Fishing and fish farming & 42 & 30 \\
Property letting & 42 & 30 \\
Wage labour & 26 & 18 \\
\hline
\end{tabular}

* PROCESSINg OF gAME AND fiSH, HANDICRAFTS BASED ON LOCAL MATERIALS AND TRADITIONS, EXTRACTION OF SAND AND gRAVEL

** BOOKKEEPINg, CONSULTANCY, CLEANINg AND SNOW CLEARINg

\section{Earning strategies in the dispersal phase of the household}

31 Unlike the households with access to property, it seems that these pluriactive households develop new market strategies in later phases of their internal development. There can be several reasons for this. The most important is probably that the households at this stage consist of only two people as the children have grown up and left home. This leaves the couple with greater economic freedom than before, and more time on their hands, so they may want to start something new. These are the households which are oriented towards new markets, and whose strategies and attitudes are close to those of category (III) householders, who are based closer to urban areas. The difference is above all that it is a tougher job to develop new enterprises in a more remote location.

\section{Rurality and the demand from the employment market}

32 Wages and salaries make up a very small part of the incomes in this type of household, and wage labour is much less common here than it was in the pluriactive farming households. Households which earn their living from local markets seem mostly to make use of several different niches in those markets, while households which exploit their farm properties to earn a living get more of their additional incomes from the open jobs market. This difference is probably due to characteristics of the labour market. There are four sectors which are seen as important sources of wage labour. $26 \%$ of the wage labourers in this group derive their incomes from the public sector (state and local authority). So it is clear that the public sector is a key sector in that it supports household-based businesses, and this is the women's sector. The other important sector is the industrial sector. This mostly consists of various different types of repair and manufacturing work for the other rural businesses, above all of agricultural implements and machinery. $22 \%$ of the wage labourers in this group work in this sector. The other 
two important sectors are the building trade and construction industry, and transport. These sectors involve work which is well suited to the qualifications possessed by men who have been socialised in the rural environment, so it is the demand from these trades which dominates the jobs market in outlying areas of Norway. It is because of the limited availability of this work that Ståle Seierstad (op. cit.) describes the rural jobs market as rationed, and when positions do become vacant, they are most readily filled by men from a farming background. It indicates, however, also that it is easier to increase the incomes from the labour market than extending the activity in the agricultural sector where the production volume is decided by the authorities.

\section{Conclusion}

The traditional working life of rural Norway exhibited certain special characteristics when compared with that of many other European countries (Berend and Ranki, 1982; Senghaas, 1985; Eythorsson, 1999). The most important of these was that rights of property ownership and access to natural resources were relatively evenly distributed. The basis of the household's economic activities was low technology haymaking for overwintering dairy cows and sheep, while cash incomes were earned from fishing and forestry. Country people, by organising farm co-operatives, created new market frameworks as a response to the modernisation of technology and the growth of the market economy. Through political protection, stable prices and good opportunities for development were assured.

Today the outlying areas are characterised by other limits on the opportunities for increasing food production. This is not due to lack of capital expenditure on equipment or to lack of available labour but because the large-scale production which new technology has made possible is too large to be applied in the Norwegian market- place. This is particularly true of milk production. Sheep farming has been affected by public policy in that the level of subsidies has been reduced, and in that the authorities have favoured the bigger farms with larger flock sizes. In many cases the farm buildings and grazing land available are big enough to support an expansion, in other cases sheep farmers would have to add to their buildings, or there is not enough grazing available to support an expansion. Businesses with greater market potential such as fishing and fishfarming have also been strictly regulated, so that in practice they are not available as options to country people who are not already established in those businesses. There is less scope within the privately run service industries as a result of population decline, and the jobs market is "rationed". Limitations on the traditional opportunities for expanding the earnings base bring the necessity of exploring new alternatives, such as providing products or services aimed at new external markets. These are either small local markets or they are very small segments of external markets.

This situation has produced two stereotypical and to a large extent mutually exclusive earning strategies in rural households in outlying regions of Norway where the income opportunities are declining (cf. table 1). The first derives from the households which own farm property. Here the households are newly established and the young couple may have taken over the property in the last few years. Succession to the farm property has occurred more because of rural values and attitudes than due to any economic rationale, as farm properties in outlying areas of Norway are not only hard to make a living from but have had little capital value until very recently. In order to keep the household above 
water financially, one partner is often working in the local labour market. In the case of the men this is often work which they have found as a result of informal qualifications acquired as part of rural working life in the phase before they established their own households. We see that both their taking over of the farm property despite the poor financial returns available and their ability to bring in significant earnings from the rationed labour market have their explanation in characteristics of the rural system they grew up in. These, then, are adaptations to declining incomes which are clearly conditioned by rural ways of life. The second stereotype is the mainly older household which is adapting to declining local markets. For various reasons they have not had access to property, which has probably meant that they started from a marginal position anyway. However, much of what they do is innovative and in this I agree with Frederick Barth and others (1966) who talk about this type of entrepreneur household whose activi228 ties are based precisely on the fact that they do not have access to the usual rural occupations. Thus they have to be innovative in order to bring in a living, and so they combine different types of market niches. It is important to emphasise that these households are in later phases of development than those in group (II); typically the children are grown up and have left home. Thus their strategies are probably based on the fact that the householders have a certain freedom of choice and the economic strength to develop new strategies. Research from areas closer to towns also showed that it was mainly households in this phase who rejected specialised adaptations in favour of developing new, experimental business activities (Eikeland, 1999).

We see therefore that the ways in which types of marginalised rural Norwegian householders handle declining incomes are determined by several different factors, such as variations in access to markets, what phases of their development the households are in and certain traits of rural ways of life. This will also have consequences for the Norwegian regional "mosaic" in that these factors encounter different conditions in the more remote areas as opposed to nearer to towns. New market opportunities and the growing demand in the labour market close to urban areas may even create new growth opportunities, despite the worsening conditions for the traditional production of foodstuffs. The outlying areas however are experiencing both weakened demand in local markets and low availability in the jobs market. This brings with it the danger of socioeconomic marginalisation, but we also see that rural ways of life contribute to changes in earning strategies which are well adapted to the new market situation.

\section{BIBLIOGRAPHY}

BARTH F. (ed.) (1972), The Role of the Entrepreneur in Social Change in Northern Norway, Oslo, Universitetsforlaget.

BERENDT I. T. \& G. RANKI (1982), The European Periphery and Industrialisation 1780-1914, London, Cambridge University Press.

BROX O (1966), Hva skjer i Nord-Norge?, Oslo, Pax. 
BROX O. og SEIERSTAD S. (1966), "Yrkeskombinasjonenes rolle i den økonomiske utviklingen i utkantstrøk”, Statsøkonomisk tidsskrift, 2.

BROX O (1980), “Mot et konsolidert bosettingsmønster?”, Tidsskrift for samfunnsforskning, 21, 3-4, pp. 227-245.

BROX O. (1984), Nord-Norge - fra allmenning til koloni, Tromsø, Universitetsforlaget.

EIKELAND S. (1997), “Fleksibilitet og berekraft. Økologiske konsekvensar av fleksibilitet i fisket”, Tidsskrift for Samfunnsforskning, 38, 1, pp. 70-95.

EIKELAND S. \& I. LIE (1999), "Pluriactivity in Rural Norway”, Journal of Rural Studies, 15, pp. 405-415.

EIKELAND S. (1999), "New Rural Pluriactivity? Household Strategies and Rural renewal in Norway”, Sociologia Ruralis, 39, pp. 359-377.

EYTHORSSON E (1999), "Rural Landscapes - Global Contexts. Settlement and Social Organisation on the North- Norwegian Coast - An Icelander's account”, in KARLSEN G. \& MESCHEROVA I. (eds.), Changing Times, Murmansk/Alta, Murmansk State Pedagogical Institute/ Finnmark College. FULLER A. M. (1990), “From Part-time Farming to Pluriactivity”, Journal of Rural Studies, 6, 4, pp. 361-373.

HERSOUG B., HOLM P. og MAURSTAD A. (1993), “Fra økonomisk rasjonalitet til økologisk fornuft", Tidsskrift for Samfunnsforskning, 34, n², pp. 101-126.

HÖJRUP T. (1983), Det glemte folk, København, Institutt for europeisk folkelivsgransking. 229 MOSL J. H. \& NILSEN R. (2000), “Kombinasjonar langs en fjord”, Nordlys (newspaper), November 15 th.

NILSEN R. (1991), "Fra fiskarbondetilpasning til nye yrkeskombinasjoner”, NLVF-publikasjon, 3.

NILSEN R. (1998), Fjordfiskere og ressursbruk i nord, Oslo, Ad Notam Gyldendal.

SEIERSTAD S. (1991), “Arbeidsmarkedskunnskap for distrikts-Norge”, Arbeidsforskningsinstiuttet rapport, 6 .

SENGHAAS D. (1985), The European Experience - A Historical Critique of the Development Theory, Leamington Spa/ Dover, Berg Publishers.

\section{NOTES}

1. The author wishes to thank researcher Einar Eythorsson at NIBR, my translator Graham Timmins and an anonymous consultant in the Journal for many valuable comments on the paper.

2. The Norwegian kommune is the basic administrative and political unit.

3. The sample consisted of the communes of Lyngen, Flakstad, Tysfjord, Hattfjelldal and Nore and Uvdal.

4. Moss is used in Northern Norway, Finland and Russia in the making of memorial wreaths and for Easter decorations. 


\section{ABSTRACTS}

Deindustrialization as well as a dramatic decrease of the labour needed in food production characterise the development on the Norwegian countryside the recent decades. This analysis examines how rural households in danger of losing income opportunities develop new income strategies in remote Norwegian areas. The regional restructuring processes have brought rural households different possibilities of making a living. The analysis takes its principal starting points in four strategic positions of rural households. They are with and without landholdings, and close and remote from urban areas. The analysis in the article puts focus on households in the most remote areas of rural Norway. I show that the households in Norwegian rural districts have maintained their traditional way of coping with the declining economic opportunities by exploiting the specific Norwegian characteristics of rural areas: the common access to land and marine resources. This kind of income obtaining is supplied by incomes from the local labour market. These strategies have their origin in the rural system of socialising which encourages the rural people to take care of their inheritance and qualify for the rural labour market. Furthermore some households without access to land areas develop several business activities that are being shared among the household members.

La désindustrialisation ainsi que la baisse dramatique de main-d'œuvre nécessaire à la production alimentaire caractérisent le développement des campagnes norvégiennes ces dernières décennies. Cette analyse examine comment des ménages ruraux menacés par la perte de leurs revenus développent de nouvelles stratégies de revenus dans des régions norvégiennes reculées. Les processus régionaux de restructuration ont rendu possible différentes façons de gagner sa vie. Cette analyse se base essentiellement sur quatre positions stratégiques des ménages ruraux: ceux-ci sont des propriétaires terriens ou non et se situent à proximité ou loin de régions urbaines. L'analyse de l'article se focalise sur les ménages des régions rurales reculées de Norvège. Nous montrerons qu'ils ont maintenu leur façon traditionnelle de lutter contre la diminution des opportunités économiques en exploitant les caractéristiques norvégiennes spécifiques des régions rurales, c'est-à-dire l'accès collectif à la terre et aux ressources marines. Cette façon de gagner sa vie est complétée par des revenus du marché du travail local. Ces stratégies prennent leur origine dans le système rural de socialisation qui encourage les habitants des campagnes à s'occuper de leur héritage et à se présenter sur le marché du travail rural. De plus, certains ménages sans accès à la terre développent différentes activités commerciales qui sont partagées au sein du ménage.

\section{INDEX}

Mots-clés: possibilités de revenus en régression, stratégies des ménages, régions peu peuplées, accès aux ressources naturelles

Keywords: declining income opportunities, household strategies, sparsely populated areas, access to natural resources 


\section{AUTHOR}

\section{SVEINUNG EIKELAND}

Research Manager, Norwegian Institute for Urban and Regional Research, Alta, Norway, sveinung.eikeland@nibr.no 